
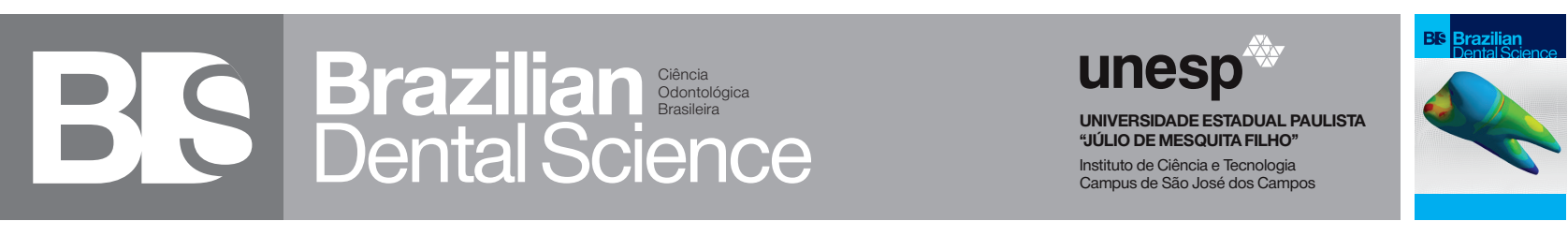

\title{
Alveolar bone loss induced by alcohol consumption in rats
}

Perda ossea alveolar induzida por consumo de álcool em ratos

\author{
Daniela Martins de SOUZA ${ }^{1}$, Alan de Aquino SILVA ${ }^{1}$, Kauê Alberto PEREIRA ${ }^{1}$, Vitor Sulz GONSALVES ${ }^{1}$, Vinicius Anéas RODRIGUES ${ }^{2}$, \\ Claudemir de CARVALHO ${ }^{1}$ \\ 1 - Faculty of Pindamonhangaba - Fundação Universitária Vida Cristã - FUNVIC - Pindamonhangaba - SP - Brazil. \\ 2 - São Paulo State University (Unesp) - Institute of Science and Technology - São José dos Campos - SP - Brazil.
}

\section{ABSTRACT}

Objectives: The aim of the present study was to assess the effect of regular and constant longterm alcohol consumption on the percentage of the remaining periodontal bone support (PBS) and periodontal bone loss (PBL) in adult rats. Material and Methods: Fifty-four (54) rats were divided into 3 groups: Control (daily water intake, $\mathrm{n}=18$ ) daily alcohol intake $(20 \%$ ethanol, $\mathrm{n}=18)$ and social alcohol intake $(20 \%$ ethanol $2 \mathrm{x}$ a week, $\mathrm{n}=18)$. The rats were treated with free-choice access to both ethanol consumption frequencies. They were euthanized after 90 days and their left mandibles were radiographed for PBS measuring. The same left mandibles were defleshed and stained. The PBL was morphometrically assessed by measuring the distance between cement-enamel junction and alveolar bone crest. Results: Did not show difference $(p>0.05)$ in the amount of consumed alcohol between the social and daily intake groups. Rats also evidenced lower PBS percentage and higher PBL $(\mathrm{p}<0.05)$ in both alcohol consumption groups in comparison to the control. Conclusion: The long-term constant and regular same amount alcohol consumption may cause alveolar bone loss and reduce the remaining periodontal bone support in adult rats. Thus, the alveolar bone loss was associated with the amount of consumed alcohol, rather than with periodicity in periodontitis-free rats.

\section{KEYWORDS}

Alveolar Bone Loss; Alcoholism; Ethanol; Periodontal Disease; X-ray.

\section{RESUMO}

Objetivo: O objetivo do presente estudo foi avaliar o efeito do consumo regular e constante de álcool em longo prazo na porcentagem do suporte ósseo periodontal remanescente (SOP) e perda óssea periodontal (PO) em ratos adultos. Material e Métodos: Cinquenta e quatro (54) ratos foram divididos em 3 grupos: Controle (ingestão diária de água, $\mathrm{n}=18)$, consumo diário de álcool $(20 \%$ etanol, $\mathrm{n}=18)$ e consumo social de álcool $(20 \%$ etanol $2 \mathrm{x}$ por semana, $\mathrm{n}=18$ ). Os ratos foram tratados com acesso de livre escolha a ambas as frequências de consumo de etanol. Eles foram sacrificados após 90 dias e suas mandíbulas esquerdas foram radiografadas para medição do SOP. As mesmas mandíbulas esquerdas foram dissecadas e coradas. A PO foi avaliada morfometricamente medindo a distância entre a junção cimento-esmalte e a crista óssea alveolar. Resultados: Não houve diferença (p> $0,05)$ na quantidade de álcool consumido entre os grupos de ingestão diária e social. Os ratos também evidenciaram menor porcentagem de SOP e maior PO ( $p<0,05)$ em ambos os grupos de consumo de álcool em comparação com o controle. Conclusão: A mesma quantidade consumida constante e regular de álcool em longo prazo pode causar perda óssea alveolar e reduzir o suporte ósseo periodontal remanescente em ratos adultos. Assim, a perda óssea alveolar foi associada com a quantidade de álcool consumido, ao invés da periodicidade em ratos sem periodontite.

\section{PALAVRAS-CHAVE}

Perda de osso alveolar; Alcoolismo; Etanol; Doença periodontal; Raio X. 


\section{INTRODUCTION}

A lcohol consumption may have an impact not only on the incidence of diseases, injuries, and other health conditions but also on other disorders and their outcomes in patients. Despite the environmental factors, alcohol-related damages are determined by the three dimensions related to its consumption, amount of consumed alcohol, drinking pattern and, in rare occasions, quality of the consumed alcohol [1].

Excessive alcohol consumption is associated with inappropriate oral hygiene and to diminished salivary flow, which leads to increased risk of developing serious oral issues [2].

Periodontium involves teeth-supporting structures, including periodontal ligament, alveolar bone and gingival tissues [3]. The alveolar processes consist of the thin alveolar bone proper forming the alveolar wall of the tooth socket, the inner and outer cortical plates, and the spongy bone of the alveolar bone proper of the cortical plates [4]. Alcohol consumption can affect the bone tissue because it causes bone tissue formation suppression due to the toxic effect of alcohol on osteoblastic activity and proliferation [5].

Rat models have been used to assess periodontal pathogenesis [6]. The influence of risk/indicator factors, such as diabetes [7], obesity induction [8], alcohol consumption $[9,10]$, estrogen deficiency [11] and alcohol intake are associated with estrogen deficiency [12], which leads to periodontium alterations.

A preview study validated the use of morphometric analysis to assess alveolar bone loss in rats because it compared morphometric and histologic procedures and found no significant differences between the two methods [13]. Also, was verified that the morphometric and radiographic are reproducible and complementary methods of assessing periodontal bone level in rats $[14,15]$.

The current study aimed to assess the effect of long-term social and constant alcohol consumption and assess the association between alcohol consumption amount and patterns of alveolar bone tissue changes in adult rats. This experimental model is relevant and innovative because we sought to reproduce in animals a situation similar to that with humans: some make constant use of alcohol and others only drink it at happy hours, on weekends.

\section{MATERIALS AND METHODS}

The total of 54 male Wistar rats was provided by the animal house of Pindamonhangaba School. The rats were subjected to acclimation for ten days before the experiment in controlled-temperature $\left(24 \pm 3^{\circ} \mathrm{C}\right)$ animal facility, under 12 -hour light/dark cycle (7 pm to $7 \mathrm{am}$ ). They fed on decent chow and filtered water ad libitum. The experimental model was carried out according to international ethical principles for animal studies in a laboratory environment. The study was approved by the Institutional Animal Research Committee (Protocol CEEA 025/2013).

\section{Experimental groups}

Fifty-four (54) rats (4 months old) were randomly distributed into three groups: control (daily water intake, $\mathrm{n}=18$ ), daily alcohol intake ( $20 \%$ ethanol, $\mathrm{n}=18$ ) and social alcohol intake ( $20 \%$ ethanol $2 \mathrm{x}$ a week, $\mathrm{n}=18$ ). The liquid diet consisted of $20 \%$ ethanol solution consumed on a daily basis and twice a week, for 90 days. Before the experimental period, the rats did not be subjected to an adaptation period for the ethanol concentration. For the daily intake group, the alcohol intake was forced: there was no supply of water during the whole treatment period. For the social intake group, there was no provision of water only on the two days of the week when the alcohol intake was forced. 


\section{Radiographic Analysis}

The left mandible was positioned in such a way that the buccal and lingual cusps of the first and second molars were superimposed and splinted in the sensor by a plastic slab. Digital radiographs were taken in the Intraoral X-ray System (Kodak 2.200 radiology Inc.Marietta/USA) using the X-Scan Duo-Micro image capture system through phosphor plates. Sensors were exposed to ionizing radiation at $65 \mathrm{Kv}$, and $7 \mathrm{~mA}$ for $0.1 \mathrm{~s}$ and the source-tosensor distance was $30 \mathrm{~cm}$ in all trials.

Two criteria had to be fulfilled to get sufficient reproducibility: teeth should not overlap each other inter-proximally, and the buccal cusp tip of the first and second molars should be superimposed on the corresponding lingual cusp tip.
Periodontal bone support (PBS) was measured through radiograph images assessed in the Image Tool software v.3.0 (UTHSCSA, San Antonio, TX, USA). All measurements were taken at the distal surface of the first mandibular molars by a single trained examiner, who did not know the group the specimen belonged to.

Three points were taken as reference: the apex of the distal root (A), the tip of the distal cusp (C) and the bottom of the deepest bony defect distal to the tooth (B). Subsequently, the apex-cusp tip (AC) and apex-deepest bone defect $(\mathrm{AB})$ distances were measured and expressed in $\mathrm{mm}$. The percentage (\%) of periodontal bone support was set by the following formula: $\mathrm{PBS}=\mathrm{AB} / \mathrm{AC} \times 100$ [14] (Figure 1).

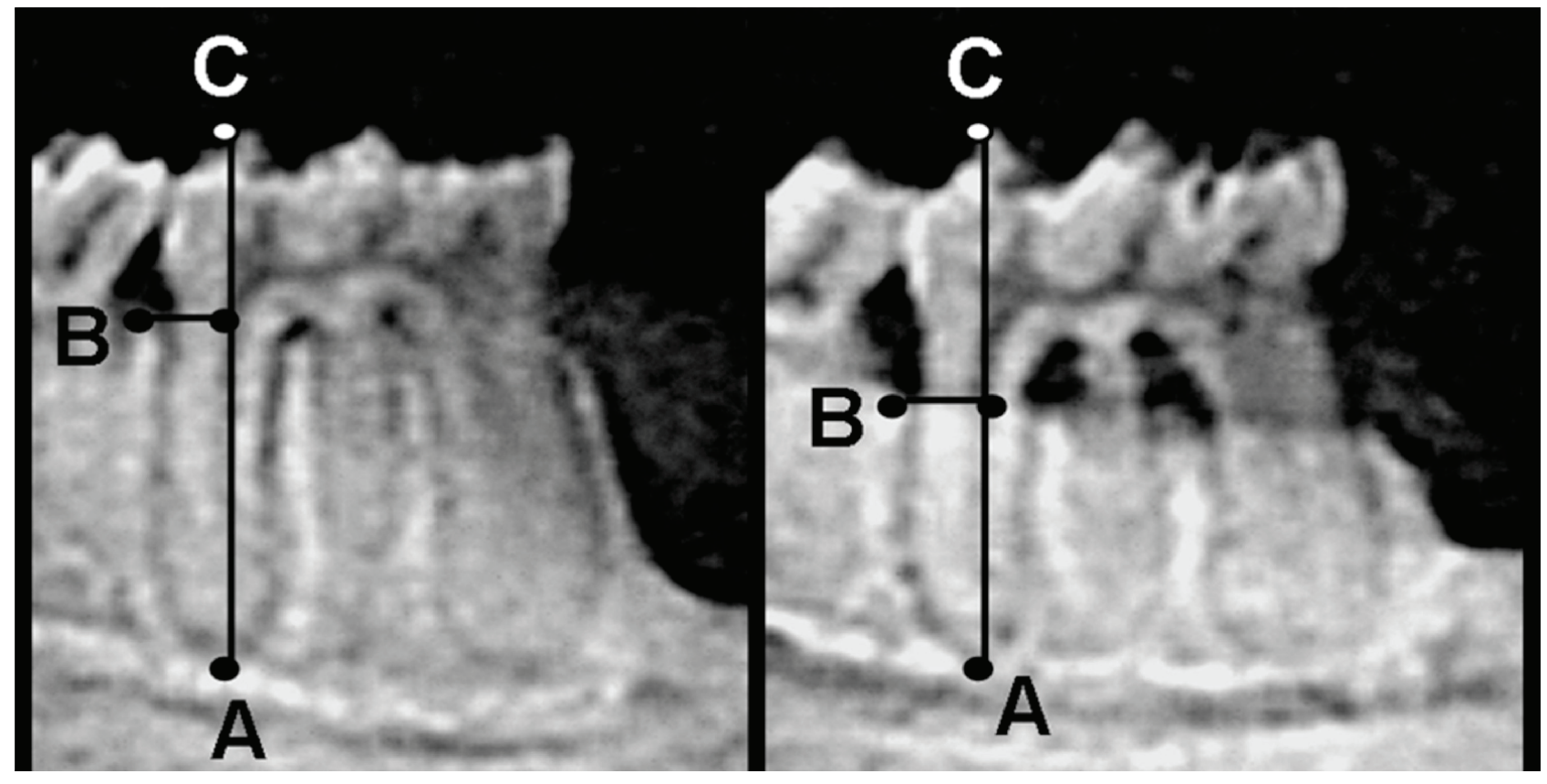

Figure 1- Periodontal bone support (PBS) in the distal side of teeth. AB indicates the distance from the apex (A) to the deepest bony defect (intersection of two lines), measured in $\mathrm{mm}$. AC indicates the distance from the apex (A) to the cusp tip (C) measured in mm. PBS (\%) is calculated according to the formula: $P B S=A B / A C \times 100$. 


\section{Morphometric Analysis}

The same left mandibles were dissected and stained with aqueous methylene blue solution (1.0\%). It was done to differ the bone from the teeth. Periodontal bone loss (PBL) was morphometrically assessed by measuring the distance between cement-enamel junction (CEJ) and alveolar bone crest (ABC). The specimens were photographed in Axiostar Microscope (Carl Zeiss, Oberkochen, Germany) (50X magnification), and PBL was measured through images assessed in the AxioVision Rel.4.6 Software (Carl Zeiss, Oberkochen, Germany).

The method described by Crawford et al. [16] to measure distances in digitized images was used to perform the linear measurements from $\mathrm{CEJ}$ to $\mathrm{ABC}$, in one-half of each root by following the axis at seven lingual sites in each mandible. Three measurements were taken in the first molar, two in the second molar, and two in the third molar. This method was also applied to the lingual aspect of the left mandible (Figure 2).

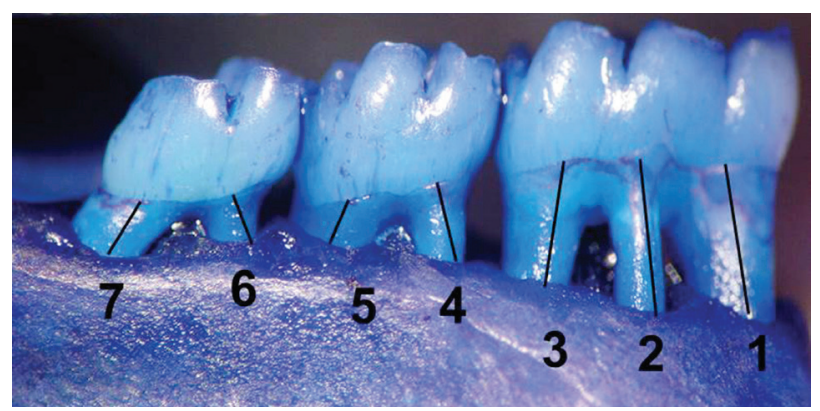

Figure 2 - Photograph of the periodontal bone loss (PBL) morphometrically assessed by measuring the linear distance between cement-enamel junction and alveolar bone crest at lingual sites in the first mandibular molar (first, second, and third molars) (X50). The lines indicate the seven distances measured in the teeth.

The mean of the measurements taken in each tooth was used to calculate the mean alveolar bone loss in each group. All measurements were taken by a single trained examiner, who did not know the origin of the specimens.

\section{Reproducibility}

Before measuring the rats, the examiner took double measurements in $25 \%$ of the specimens in one-week intervals. There were no differences between the mean values recorded through the radiographic $(p=0.0844)$ and morphometric methods $(\mathrm{p}=0.1707)$. The Pearson's correlation coefficient of the two sets of measurements indicated quite strong correlation in both the radiographic (99\%: $\mathrm{r}=0.8143, \mathrm{p}=0.000)$ and morphometric methods (99\%: $r=0.9603, p=0.000$ ).

\section{Statistical Analysis}

The liquid diet was assessed as the mean and standard deviation of both alcohol intake groups during the experimental period. The independent sample t-test $(\mathrm{p}<0.05)$ was used to compare the amount of consumed ethanol to consumption frequency.

The data were expressed as a mean and standard deviation of the radiographic (\%) and morphometric $(\mathrm{mm})$ analyses. The oneway analysis of variance (ANOVA), and the Tukey test adopted for subsequent multiple comparisons $(\mathrm{p}<0.05)$, were applied to find significant periodontal bone support and periodontal bone loss differences between groups treated with alcohol and the control.

\section{RESULTS}

\section{Diet Analysis}

The daily ethanol intake group consumed $50.96 \pm 16.13 \mathrm{ml} / \mathrm{d}$ of alcohol solution, on average. The social ethanol intake group consumed $47.65 \pm 13.27$ of $\mathrm{ml} / \mathrm{d}$ of alcohol solution, on average. Results did not show statistically significant difference $(p=0.1435)$ between the daily intake and the twice-a-week intake groups. 


\section{Radiographic Analysis}

The data analysis evidenced significant differences $(\mathrm{p}<0.05)$ in the PBS percentage (Table 1) presented by both alcohol consumption groups in comparison to the control. The analysis showed less periodontal bone support in the daily alcohol intake (59.11 $\pm 1.94 \%)$ and social alcohol intake groups $(58.56 \pm 3.32 \%)$ than in control (69.49 \pm $2.38 \%)$.

\section{Morphometric Analysis}

The morphometric analysis showed greater $(\mathrm{p}<0.05)$ morphometric periodontal bone loss in the daily alcohol intake (1.03 \pm $0.11 \mathrm{~mm}$ ) and social alcohol intake groups $(0.98 \pm 0.10 \mathrm{~mm})$ than in control $(0.84 \pm 0.10$ mm) (Table 1).

Table 1 - Mean and standard deviation of periodontal bone support (PBS; \%) and periodontal bone loss (PBL; mm) for test and control groups

\begin{tabular}{|c|c|c|}
\hline Groups & PBS (\%) & PBL (mm) \\
\hline daily alcohol & $59.11 \pm 1.94$ & $1.03 \pm 0.11$ \\
\hline social alcohol & $58.56 \pm 3.32$ & $0.98 \pm 0.10$ \\
\hline Control & $69.49 \pm 2.38^{\star}$ & $0.84 \pm 0.10^{*}$ \\
\hline$p^{*}$ & 0.0000 & 0.0028 \\
\hline
\end{tabular}

*Statistically significant (ANOVA and Tukey test; $p<0.05$ ) in columns.

\section{DISCUSSION}

The present study was designed to assess the effect of long-term daily and social alcohol intake (90 days) on alveolar bone loss in rats treated with free-choice access to both ethanol consumption groups. Results evidenced that both consumption frequencies worsened the periodontal bone damages and showed no statistically significant difference among different amounts of consumed alcohol.

Several methods have been applied to assess periodontal bone loss in rats through morphometric $[7,8,10,11,17,18]$, radiographic
$[7,19]$, and histologic [12] or histometric [9] analyses applied to jaws. However, the morphometric methods adopted to assess alveolar bone level are not capable of detecting intra-osseous defects. Therefore, an additional radiographic method was proposed by Klausen et al. [14], and both methods were used in the present study.

Harmful alcohol intake causes high disease, the social and economic burden to society. Most diseases and injuries caused by alcohol intake impact have a dose-response relation to the amount of consumed alcohol [20]. The amount of consumed alcohol is particularly relevant when the association between alcohol and chronic diseases is taken into account [1]. The results of present study showed no significant difference between the amounts of ethanol daily consumed, and that consumed twice-a-week; therefore, the volume-dependent relation to alveolar bone loss appears to be consistent with its effects on bone tissue.

Not only the amount of consumed alcohol but also the drinking pattern over time affects the risk of harmful effects; for example, drinking during the meals seems to be associated with the low development of chronic diseases than the same pattern in other times of the day [1]. The results obtained in this study showed no difference in the bone changes associated with frequencies of alcohol consume.

Heavy drinking episodes at the population level are defined as the consumption of 60 or more grams of pure alcohol $(6+$ standard drinks in most countries) at least once a month. The amount of consumed alcohol in a single occasion is important because it has many acute consequences such as poisoning, injury, and violence, besides the impact in countries where alcohol intoxication is socially disapproved. Heavy drinking episodes are associated with detrimental consequences, even when the mean alcohol consumption level is relatively low [1]. 
Some studies [9,10,18,19,21-24] showed that alcohol intake itself might not be capable of causing bone loss in rats' periodontium. On the other hand, other studies [25,26] recorded that chronic alcohol drinking itself may cause bone loss in rats. These results are corroborated by the results in the present study.

Souza and Rocha [22] found that chronic ethanol intake, associated with its low (22\%) or high (36\%) caloric values, may not be capable of causing bone loss in unligated rats. Similar findings were observed in the study by Souza et al. [18], who also observed that alcohol consumption at concentrations 10 and 20\% might not be capable of causing an alveolar bone loss in rats without ligature-induced periodontitis.

Irie et al. [25] showed that the distance between the cement-enamel junction and alveolar bone crest was longer in the alcohol intake group free of induced periodontitis than in control. Bannach at al. [26] showed that the distance between the cement-enamel junction and alveolar bone crest from the palatal site of the first mandibular molar was longer in the alcohol intake group than in the control group without periodontitis. Similarly, the present study showed that alcohol consumption itself might cause an alveolar bone loss in rats.

Studies about the possible biological mechanisms involving bone tissue, as well as longitudinal studies, are required to confirm the role of alcohol consumption in the worsening of alveolar bone loss.

\section{CONCLUSIONS}

The long-term constant and regular alcohol consumption may cause alveolar bone loss and reduce the remaining periodontal bone support in adult rats when it is associated with the amount of consumed alcohol, rather than with its frequency in periodontitis-free rats.

\section{ACKNOWLEDGMENT}

The authors thank IPRO (Pindense Institute of Radiology) for providing the Intraoral X-ray System (Kodak 2.200) and for his technical support. They also thank the Dentistry Department of the University of TaubateUNITAU for providing the Microscope Axiostar (Carl Zeiss, Oberkochen, Germany).

\section{REFERENCES}

1. World Health Organization. Global status report on alcohol and health. 2014. Geneva (http://apps.who.int/iris/ bitstream/10665/112736/1/9789240692763_eng.pdf).

2. Cope GF. Alcohol and recreational drug use: The effect on oral health. Dent Nursing. 2012 Jan;8(1):22-5.

3. Kinane DF. Causation and pathogenesis of periodontal disease. Periodontol 2000. 2001;25:8-20.

4. Cho MI, Garant PR. Development and general structure of the periodontium. Periodontol 2000. 2000 0ct;24:9-27.

5. Amaral C da S, Luiz RR, Leão AT. The relationship between alcohol dependence and periodontal disease. J Periodontol. 2008 Jun;79(6):993-8.

6. Weinberg MA, Bral M. Laboratory animal models in periodontology. J Clin Periodontol. 1999;26(6):335-40.

7. de Souza DM, Medeiros AC, Santos J0, Lima MCM, de Aquino SA. Spontaneous Alveolar Bone Loss Development by Alloxan-induced Diabetes Mellitus in Rats. Int J Adv Med Sci. Nov; 2015;3(2):37-44.

8. Gonçalves AF, Ribeiro DC, Zanin MT, Carvalho C, Souza DM. Effect of obesity on the alveolar bone level of rats. Revista Ciência e Saúde On-line. 2017;2(1):22-28.

9. Souza DM, Ricardo LH, Rocha RFD. Effects of alcohol intake in periodontitis progression in female rats: a histometric study. Braz $\mathrm{J}$ Oral Sci. 2014;13(3):229-34.

10. de Souza DM, da Rocha RF. Influence of variable concentration of ethanol intake on alveolar bone loos in rats periodontitis model. Rev Odonto Ciênc. 2014;29(3):76-80.

11. Amadei SU, Souza DM, Brandão AAH, Rocha RF. Influence of different durations of estrogen deficiency on alveolar bone loss in rats. Braz Oral Res. 2011;25:538-43

12. Alonso JM, de Souza DM, Balducci I, da Rocha RF. Periodontal inflammation induced by chronic ethanol consumption in ovariectomized rats. Braz Dent Sci. 2016;19(1):60-9.

13. Fernandes MI, Gaio EJ, Oppermann RV, Rados PV, Rösing CK. Comparison of histometric and morphometric analyses of bone height in ligature-induced periodontitis in rats. Braz Oral Res. 2007;21(3):216-21.

14. Klausen B, Evans RT, Sfintescu C. Two complementary methods of assessing periodontal bone level. Scand J Dent Res. 1989;97:494-9.

15. Souza DM, Rosa LP, Ricardo LH, Moraes LC, Rocha RF. Avaliação óssea alveolar de rattus norvegicus por meio dos métodos radiográfico e morfométrico. Cienc 0dontol Bras. 2005;8(4):77-84. 
16. Crawford JM, Taubman MA, Smith D J. The natural history of periodontal bone loss in germfree and gnotobiotic rats infected with periodontopathic microorganisms. J Periodontol Res. 1978;13(4):316-25.

17. Souza DM, Prado F de A, Prado M de A, Rocha RF, Carvalho,YR. Evaluation of two morphmetric methods of bone loss percentages caused by periodontitis in rats in different location. J Appl Oral Sci. 2010;18:493-7.

18. Souza DM, Ricardo LH, Kantoski KZ, Rocha RF. Influence of alcohol consumption on the alveolar bone level associated with ligatureinduced periodontitis in rats. Braz Oral Res. 2009;23:326-32.

19. Souza DM, Ricardo LH, Prado MA, Prado FA, Rocha RF. The effect of alcohol consumption on periodontal bone support in experimental periodontitis in rats. J Appl Oral Sci. 2006;14:443-7.

20. Rehm J, Room R, Graham K, Monteiro M, Gmel G, Sempos CT. The relationship of average volume of alcohol consumption and patterns of drinking to burden of disease A An overview. Addiction. 2003;98(9):1209Å28.

21. Surkin PN, Ossola CÁ, Mohn CE, Elverdin JC, Fernández Solari J. Chronic alcohol consumption alters periodontal health in rats. Alcohol Clin Exp Res. 2014 Jul;38(7):2001-7.
22. Souza DM, Rocha RF. Low caloric value of ethanol itself increases alveolar bone loss in ligature-induced periodontitis in male rats. Braz Oral Res. 2009 0ct;23(4):460-6.

23. Bastos MF, Gaag GLD, Romero JR, Gabrili JJM, Marques MR, Duarte PM. Effects of Cachaça, a typical Brazilian alcoholic beverage, on alveolar bone loss and density: A study in peripubertal rats. Arch Oral Biol. 2014 Jan;59(1):82-91.

24. Wagner MC, Rocha JMD, Gaio EJ, Cavagni J, Carrard VC, Rösing CK. Effect of $15 \%$ Alcohol Dependence on Alveolar Bone Loss and TNF- $\alpha$ Secretion in Wistar Rats. Braz Dent J. 2016 Apr;27(2):13540.

25. Irie K, Tomofuji T, Tamaki N, Sanbe T, Eruni D, Azuma T, et al. Effects of ethanol consumption on periodontal inflammation in rats. J Dent Res. 2008;87:456-60.

26. Bannach SV, Teixeira FB, Fernandes LM, Ferreira RO, Santana LN, Fontes-Júnior EA, et al. Alveolar bone loss induced by chronic ethanol consumption from adolescence to adulthood in Wistar rats. Indian J Exp Biol. 2015 Feb;53(2):93-7.

\section{Daniela Martins de Souza}

(Corresponding address)

Rua Marechal Deodoro da Fonseca, 316 - Centro,

CEP: 12 401-010,

Pindamonhangaba - Brazil,

Phone: +55 12 3648-8323

Date submitted: 2017 Jul 28

e-mail: danimart.voy@gmail.com 